\title{
Factors influencing staff motivation in organised retail sector in Kolkata, India
}

\author{
Gairik Das \\ Sohini Dutta \\ IISWBM, Kolkata, India
}

\section{Key Words}

Cash benefit structures, career growth opportunities, incentive structure, organised retail sector, reward and recognition structure, staff motivation.

\begin{abstract}
Purpose of Research: The present paper studies the effectiveness of the factors in motivating the employees working in the retail industry. It also analyses the perception of the employees about the effectiveness of the factors influencing staff motivation and the difficulties faced by them in their workplace and their opinions on being better off. This study is very crucial in present day context as competition in retailing is getting steeper. Particularly after the economic slowdown in a highly volatile economic environment, retailers must analyse the factors affecting their employee motivation.

Methodology: In this study, the researchers have tended to highlight the positivist philosophical approach. The research has been carried through the survey done on the staffs of operations and sales team of some top organised retailers in Kolkata by a standardised questionnaire, blended with open ended and close ended questions. It also delves into the effect of demographics and psychology of the staffs and their perception about the factors influences their motivation level in the workplace, by using various statistical tools like Chi-Square Test, Cronbach's Alpha and Factor Analysis in the study.

Findings: Reward and Recognition structure and Cash Benefit structures are the most influential factors in motivating the staffs to work in retail sector, closely followed by Career growth opportunities. Again, the Incentive structure influences the staff motivation to perform better in sales.

Practical Implications and Conclusions: The components give an unadulterated and fulfilling experience to the staffs which makes them feel good about their work and also make them feel hopeful in order to make betterment in their career. These leads to positively influencing the motivation level of the staffs in the retail industry. This leads to better performance from the staffs in both quality and quantity. This also reduces employee turnover. This helps in maintaining a healthy environment work balance with a healthy relationship between the staffs and the management, in the retail sector. This in turn helps the retail sector to grow and prosper.
\end{abstract}

\section{Introduction}

Quality of service is a leading criterion of excellence for most retailers and the quality of service is wholly dependent on employee service providers. Disgruntled, detached, and slothful employees can damage a retailer's bottom line as much as a big-box store locating across the street. Thus, employee motivation is one of the hottest, yet confusing, topics in the retail industry. Everybody wants the Rosetta stone to unlock the secrets of retail employee motivation.

Retail is a fast-paced and competitive environment, so it's no surprise that setting attainable goals is a huge motivating factor for employees. An easy way to motivate retail employees and work toward the company's goals is to create competitions encouraging employees to strive for those goals. To make sure these goals are attainable, otherwise those targets will just exhaust employees who already struggle with burnout. Offering more responsibility to the employees, the company can demonstrate that they're invested in their professional growth and see them as more than just an "asset" for the business. The monotony of a retail job can quickly make employees disengage, and so rewarding the employees with more responsibility and recognizing retail employees for their effort is the true key to motivating them. Recognition can come in many forms: verbal, peer-to-peer, manager-to-peer, and more. Employees, especially those who work in retail thrive on recognition for a job well-done. It is to be also made sure that the employees are empowered to voice their opinions about what the company could do better. The employees should be encouraged to share their opinions. Again, providing a clear path forward is an easy way to motivate retail employees. Sometimes the best way to motivate retail employees is to break out of 
the monotony of a day with a nice surprise for the employees. A surprise as simple as pizza for lunch or cookies in the break room can change an employee's entire attitude at work. There are plenty more ways to surprise employees.

\section{Literature Review}

Employee Motivation is widely exercised now across all corporate sectors including retail. The concept of motivation comes from a Latin word "movere" which suggests "to move" and motivation is what moves the staff from weariness to attention (Mohsan et al., 2004). Another definition is an action that stimulates an employee to require a course of action, which is able to cause attain some goal or to satisfy certain psychological needs of employee (George and Sabapathy, 2011). Robbins and Judge (2008) defined motivation because the processes that account for somebody's intensity, direction, and persistence of effort toward achieving goal. Motivation encompasses a persistence dimension. This is often a measure of how long someone can maintain effort (Robbins and Judge, 2008). There are two styles of motivation, intrinsic motivation, and extrinsic motivation (Thomas \& Velthouse, 1990, Mohsan et al., 2004, Gagne, 2005, Dwivedula et al., 2011, George and Sabapathy, 2011). (Thomas and Velthouse, 1990) defined intrinsic motivation as "a positively valued experiences that a personal employee gets directly from their work tasks", stems from an instantaneous relationship between the doer and also the task (George and Sabapathy, 2011), rely upon employee's volition to predict her behavior (Dwivedula et al., 2011). They're self-motivated because they enjoy performing the particular tasks or enjoy the challenge of successfully completing the tasks (Mohsan et al., 2004). The self- generated factors, that affect people to behave in an exceedingly particular way or to maneuver during a particular direction includes responsibility, freedom to act, scope to use and develop skills and skills, interesting and challenging work, and opportunities for advancement. Feelings of feat, accomplishment and competence-derived from performing one's job are samples of intrinsic motivators and its associated with 'psychological' rewards (George and Sabapathy, 2011). Extrinsic motivation stems from the external work environment to the task and is typically applied by someone aside from the person being motivated (George and Sabapathy, 2011), the external motivation maintains that the link between individual's motives and therefore the behavior is moderated by the individual's affection, and cognition of the outcomes (Dwivedula et al., 2011). Extrinsic motivation is expounded to 'tangible' rewards in (George and Sabapathy, 2011). Employees who are externally motivated, generally don't enjoy the tasks but are motivated to perform well by some reward, pay, promotion, praise, or ovoid any negative consequences (Mohsan et al., 2004). The discussion on the inner and external basis of motivation concludes that job motivation could be a multi-dimensional concept (Dwivedula et al., 2011). Charles \& Marshall (1992) found that the highest motivators for workers were: good wages, good working conditions, and appreciation for employment well done. (Simon and Enz, 1995) found, within their studies in the U.S.A and Canada the motivation factors of hotel workers are 1. Good Wages 2. Job Security. 3. Promotion \& growth within the organization. 4. Good working conditions 5. Interesting Work. 6. Full Appreciation of labour done 7. Personal loyalty to employees. 8. Feeling of being "in on things". 9. Tactful Discipline. 10. Sympathetic help with personal problems. Tella et al. (2007) stated, Strategies of motivating Workers as follow:- Salary, Wages and Conditions of Service: personnel managers must consider four major components of a salary structures these are the duty rate, which relates to the importance the organization attaches to every job; payment, which inspires workers or groups by rewarding them consistent with their performance; personal or special allowances, related to factors like scarcity of particular skills or certain categories of data professionals or librarians, or with long service; and fringe benefits like holidays with pay, pensions, and so on. Money: this is often done through the method of rewarding employees for higher productivity by instilling fear of loss of job (e.g., premature retirement because of poor performance). The need to be promoted and earn enhanced pay might also motivate workers. Staff Training: Staff training is a substantial strategy for motivating employees. Information Availability and Communication: Information availability brings in contact a robust peer pressure, where two or more people running together will run faster than when running alone or running without awareness of the pace of the opposite runners. By sharing information, subordinates compete with each other. Today organizations from all round the world struggle to motivate its employees so as to survive and compete in dynamic corporate environment successfully as motivation puts human resources into action, improves level of efficiency of employees, enables the organizations to 
achieve sustainable competitive advantage and ultimately ends up in attain organizational goals (Mohsan et al., 2004).

\section{Research Methodology}

In this research, the researchers have tended to highlight the positivist philosophical approach. As the data collected is also influenced by its external environments and does not exist without individual bias of respondents.

\subsection{Hypothesis Formulation}

Hypothesis building directs the researcher to the concepts that should be studied in order to get answers to the research questions (Ghauri \& Gronhaug, 2002). According to the research questions listed above the hypotheses will be formulated as follows:

Ho1: There is a relationship between the influence of staff motivation factors and the staff performance.

Ha1: There is no relationship between the influence of staff motivation factors and the staff performance.

In the first hypothesis, the independent variables consist of the influence of staff motivation factors and the dependent variable is the staff performance.

Ho2: There is a relationship between the influence of staff motivation factors and the level of staff satisfaction at work.

Ha2: There is no relationship between the influence of staff motivation factors and the level of staff satisfaction at work.

In the second hypothesis, the independent variables are the influence of staff motivation factors, and the dependent variable is the level of staff satisfaction at work.

\subsection{Research Technique}

The type of research technique used in this case is that of survey. The information gathered from the secondary sources / literature review has helped in the formation of the questionnaire. The survey questionnaire had primarily three sections. The first section was designed primarily to collect the demographic data of the respondents. The second part of the questionnaire contains a number of statements. It aims to identify the factors influencing the motivation of the employees. The third section had few open-ended questions, where the respondents were free to express their opinions according to the asked question. The sample size for the survey was 90 . Convenient random sampling technique was followed during the research. The researcher tried to target both male and female respondents across different age groups, who are a part of the operations and sales department of the retail stores. Before administering the final questionnaire, the questionnaire was tested in a pilot study.

\section{Results}

\subsection{Results of Chi-Square Test}

Table 1: Relationship of career growth opportunities with its significant variables

\begin{tabular}{|l|l|l|l|}
\hline Statement/Question & Variables & Pearson Chi-Square Value & $\begin{array}{l}\text { Significant/ } \\
\text { Not Significant }\end{array}$ \\
\hline $\begin{array}{l}\text { Retail industry provides } \\
\text { enough opportunities to } \\
\text { grow in career }\end{array}$ & Educational Qualification & 0.001 & Significant \\
\cline { 2 - 4 } & Present Designation & 0.000 & Significant \\
\hline
\end{tabular}

From Table 1, the relationship between the availability of career growth opportunities in retail industry and the educational qualifications of the employees is strongly significant. The availability of career growth opportunities in retail industry is highly significant depending on the present designation of the employees. 
Table 2: Relationship of satisfaction level on career growth opportunities with its significant variables

\begin{tabular}{|l|l|l|l|}
\hline Statement/Question & Variables & $\begin{array}{l}\text { Pearson } \\
\text { Square Value }\end{array}$ & $\begin{array}{l}\text { Chignificant/ } \\
\text { Not Significant }\end{array}$ \\
\hline \multirow{2}{*}{$\begin{array}{l}\text { How satisfied are the } \\
\text { employees about the career } \\
\text { growth opportunities in } \\
\text { retail industry? }\end{array}$} & Educational Qualification & 0.001 & Significant \\
\cline { 2 - 5 } & Present Designation & 0.000 & Significant \\
\cline { 2 - 5 } & Next Target Designation & 0.004 & Significant \\
\cline { 2 - 5 } & Tnitial Designation & 0.000 & Significant \\
\cline { 2 - 4 } & Tetal Years Working in Retail Industry & 0.000 & Significant \\
\cline { 2 - 4 } & Sears working in the present Designation & 0.002 & \\
\hline
\end{tabular}

From Table 2, the satisfaction of the employees about the career growth opportunities available in the retail industry is significantly related with the educational qualifications, next target designation and no. of years of working in the present designation of the employees. It is also strongly significant depending on the present designation, total years of working in the retail industry and the initial designation of the employees.

Table 3: Relationship of satisfaction level on leave structure with its significant variables

\begin{tabular}{|l|l|l|l|}
\hline Statement/Question & Variables & $\begin{array}{l}\text { Pearson } \\
\text { Square Value }\end{array}$ & $\begin{array}{l}\text { Chignificant/ } \\
\text { Not Significant }\end{array}$ \\
\hline \multirow{2}{*}{$\begin{array}{l}\text { How satisfied are the } \\
\text { employees with the leave } \\
\text { structure? }\end{array}$} & Age & 0.031 & Significant \\
\cline { 2 - 4 } & Marital Status & 0.043 & Significant \\
\cline { 2 - 4 } & Educational Qualifications & 0.039 & Significant \\
\cline { 2 - 4 } & Next Target Designation & 0.034 & Significant \\
\cline { 2 - 4 } & Total Years Working in Retail Industry & 0.000 & Significant \\
\cline { 2 - 4 } & Years Working in Present Designation & 0.010 & Significant \\
\hline
\end{tabular}

From Table 3, the satisfaction of the employees about the leave structure is significantly related to age, marital status, educational qualifications, next target designation and no. of years of working in the present designation of the employees. It has a strong significant relationship with the total years of working experience in the retail industry of the employees.

Table 4: Relationship of satisfaction level on reward and recognition structure with its significant variables

\begin{tabular}{|l|l|l|l|}
\hline Statement/Question & Variables & $\begin{array}{l}\text { Pearson } \\
\text { Square Value }\end{array}$ & $\begin{array}{l}\text { Shignificant/ } \\
\text { Not Significant }\end{array}$ \\
\hline \multirow{2}{*}{$\begin{array}{l}\text { How satisfied are the } \\
\text { employees about the }\end{array}$} & Educational Qualifications & 0.000 & Significant \\
\cline { 2 - 4 } $\begin{array}{l}\text { reward and recognition } \\
\text { structure in retail } \\
\text { industry? }\end{array}$ & Present Designation & 0.008 & Significant \\
\cline { 2 - 4 } & Next Target Designation & 0.036 & Significant \\
\cline { 2 - 4 } & Initial Designation & 0.025 & Significant \\
\cline { 2 - 4 } & Total Years Working in Retail Industry & 0.000 & Significant \\
\cline { 2 - 4 } & Years Working in Present Designation & 0.000 & Significant \\
\hline
\end{tabular}

From Table 4, the satisfaction of the employees about the reward and recognition structure is significantly related with the present designation, next target designation and initial designation of the employees. It possesses strong significant relationship with the educational qualifications, total years of working experience in the retail industry and the years of working in the present designation of the employees.

Table 5: Relationship of satisfaction level on cash benefit structure with its significant variables

\begin{tabular}{|l|l|l|l|}
\hline Statement/Question & Variables & $\begin{array}{l}\text { Pearson } \\
\text { Square Value }\end{array}$ & $\begin{array}{l}\text { Chi- } \\
\text { Significant/ } \\
\text { Not Significant }\end{array}$ \\
\hline \multirow{2}{*}{$\begin{array}{l}\text { How satisfied are the } \\
\text { employees with the cash } \\
\text { benefit structure? }\end{array}$} & Educational Qualifications & 0.000 & Significant \\
\cline { 2 - 4 } & Initial Designation & 0.011 & Significant \\
\cline { 2 - 4 } & Total Years Working in Retail Industry & 0.038 & Significant \\
\cline { 2 - 4 } & Years Working in Present Designation & 0.009 & Significant \\
\hline
\end{tabular}

From Table 5, the satisfaction of the employees about the cash benefit structure is significantly related with the educational qualifications, initial designation, total years of working experience in the retail industry and years of working experience in the present designation of the employees. 
Table 6: Relationship of satisfaction level on incentive structure with its significant variables

\begin{tabular}{|l|l|l|l|}
\hline Statement/Question & Variables & $\begin{array}{l}\text { Pearson } \\
\text { Square Value }\end{array}$ & $\begin{array}{l}\text { Significant/ } \\
\text { Not Significant }\end{array}$ \\
\hline \multirow{2}{*}{$\begin{array}{l}\text { How satisfied are the } \\
\text { employees with } \\
\text { incentive structure? }\end{array}$} & Present Designation & 0.000 & Significant \\
\cline { 2 - 4 } & Next Target Designation & 0.005 & Significant \\
\cline { 2 - 4 } & Initial Designation & 0.007 & Significant \\
\cline { 2 - 4 } & Total Years Working in Retail Industry & 0.000 & Significant \\
\cline { 2 - 4 } & Years Working in Present Designation & 0.018 & Significant \\
\hline
\end{tabular}

From Table 6, the satisfaction of the employees on incentive structure is significantly related to the present designation, next target designation and the initial designation of the employees. It has a significant relationship with the total years of work in retail industry and also years of working in the present designation of the employees.

Table 7: Relationship of requirement of changes in incentive structure with its significant variables

\begin{tabular}{|l|l|l|l|}
\hline Statement/Question & Variables & $\begin{array}{l}\text { Pearson } \\
\text { Square Value }\end{array}$ & $\begin{array}{l}\text { Significant/ } \\
\text { Not Significant }\end{array}$ \\
\hline \multirow{2}{*}{$\begin{array}{l}\text { Requirement of changes in } \\
\text { the incentive structure felt } \\
\text { by the retail employees. }\end{array}$} & Age & 0.021 & Significant \\
\cline { 2 - 4 } & Marital Status & 0.015 & Significant \\
\cline { 2 - 4 } & Educational Qualifications & 0.017 & Significant \\
\cline { 2 - 4 } & Present Designation & 0.000 & Significant \\
\cline { 2 - 4 } & Initial Designation & 0.003 & Significant \\
\cline { 2 - 4 } & Total Years Working in Retail Industry & 0.000 & Significant \\
\cline { 2 - 4 } & Years Working in Present Designation & 0.005 & Significant \\
\hline
\end{tabular}

From Table 7, the feeling of the requirement of changes in the incentive structure in the employees is significantly related with the age, marital status, educational qualifications, initial designation, and years of working experience in the present designation of the employees. It is strongly significant depending on the present designation and the total years of working experience in the retail industry of the employees.

Table 8: Relationship of requirement of trainings with its significant variables

\begin{tabular}{|l|l|l|l|}
\hline Statement/Question & Variables & $\begin{array}{l}\text { Pearson } \\
\text { Square Value }\end{array}$ & $\begin{array}{l}\text { Significant/ } \\
\text { Not Significant }\end{array}$ \\
\hline \multirow{2}{*}{$\begin{array}{l}\text { Requirement of trainings } \\
\text { for the retail employees. }\end{array}$} & Age & 0.010 & Significant \\
\cline { 2 - 4 } & Marital Status & 0.002 & Significant \\
\cline { 2 - 4 } & Educational Qualifications & 0.003 & Significant \\
\cline { 2 - 4 } & Total Years Working in Retail Industry & 0.000 & Significant \\
\cline { 2 - 4 } & Years Working in Present Designation & 0.000 & Significant \\
\hline
\end{tabular}

From Table 8, the relationship the requirement of trainings by the employees is significant with the age, marital status, and the educational qualifications of the employees. Total years of working experience in the retail industry and years of working experience in the present designation of the employees have strong significance on the requirement of the trainings by the employees.

Table 9: Relationship of motivation level of the employees to work in retail industry with its significant variables

\begin{tabular}{|l|l|l|l|}
\hline Statement/Question & Variables & $\begin{array}{l}\text { Pearson } \\
\text { Square Value }\end{array}$ & $\begin{array}{l}\text { Chi- } \\
\text { Significant/ } \\
\text { Not Significant }\end{array}$ \\
\hline $\begin{array}{l}\text { Motivation level of the } \\
\text { employees to work in retail } \\
\text { industry. }\end{array}$ & Educational Qualifications & 0.002 & Significant \\
\cline { 2 - 4 } & Total Years Working in Retail Industry & 0.043 & Significant \\
\cline { 2 - 4 } & Years Working in Present Designation & 0.023 & Significant \\
\hline
\end{tabular}

From Table 9, the motivation of the employees to continue working in the retail industry is significantly related with the educational qualifications, total years of working experience in the retail industry and the years of work experience in the present designation of the employees. 
Table 10: Relationship of achieved rewards with its significant variables

\begin{tabular}{|l|l|l|l|}
\hline Statement/Question & Variables & $\begin{array}{l}\text { Pearson Chi-Square } \\
\text { Value }\end{array}$ & $\begin{array}{l}\text { Significant/ } \\
\text { Not Significant }\end{array}$ \\
\hline \multirow{3}{*}{$\begin{array}{l}\text { Achievement of rewards } \\
\text { by the retail employees }\end{array}$} & Age & 0.010 & Significant \\
\cline { 2 - 4 } & Marital Status & 0.007 & Significant \\
\cline { 2 - 4 } & Educational Qualifications & 0.007 & Significant \\
\cline { 2 - 4 } & Present Designation & 0.001 & Significant \\
\cline { 2 - 4 } & Initial Designation & 0.002 & Significant \\
\cline { 2 - 4 } & Total Years Working in Retail Industry & 0.001 & Significant \\
\cline { 2 - 4 } & Years working in the present Designation & 0.000 & Significant \\
\hline
\end{tabular}

From Table 10, the achievement of rewards is significantly related with the age, marital status, and educational qualifications of the employees. It is also having significant influences on the present designation, initial designation, total years of working in retail industry and years of working experience in the present designation of the employees.

Table 11: Relationship of perception of the employees about the best factor about working in retail industry with its significant variables

\begin{tabular}{|l|l|l|l|}
\hline Statement/Question & Variables & $\begin{array}{l}\text { Pearson } \\
\text { Square Value }\end{array}$ & $\begin{array}{l}\text { Chignificant/ } \\
\text { Not Significant }\end{array}$ \\
\hline \multirow{3}{*}{$\begin{array}{l}\text { Best factor about working } \\
\text { in retail industry }\end{array}$} & Age & 0.004 & Significant \\
\cline { 2 - 4 } & Marital Status & 0.000 & Significant \\
\cline { 2 - 4 } & Educational Qualifications & 0.008 & Significant \\
\cline { 2 - 4 } & Present Designation & 0.012 & Significant \\
\cline { 2 - 4 } & Initial Designation & 0.014 & Significant \\
\cline { 2 - 4 } & Total Years Working in Retail Industry & 0.000 & Significant \\
\cline { 2 - 3 } & Years Working in Present Designation & 0.000 & Significant \\
\hline
\end{tabular}

From Table 11, the perception of the employees on the best factor about working in the retail industry is significantly related with age, educational qualifications, present designation, and initial designation of the employees. It is also having strong and significant relationship with the marital status, total years of working experience in the retail industry and years of working experience in the present designation of the employees.

Table 12: Relationship of the employees referring people to work in retail industry with its significant variables

\begin{tabular}{|l|l|l|l|}
\hline Statement/Question & Variables & $\begin{array}{l}\text { Pearson } \\
\text { Square Value }\end{array}$ & $\begin{array}{l}\text { Chignificant/ } \\
\text { Not Significant }\end{array}$ \\
\hline $\begin{array}{l}\text { Retail employees referring } \\
\text { people to join the retail } \\
\text { industry. }\end{array}$ & Educational Qualifications & 0.002 & Significant \\
\cline { 2 - 5 } & Total Years Working in Retail Industry & 0.043 & Significant \\
\cline { 2 - 5 } & Years Working in Present Designation & 0.023 & Significant \\
\hline
\end{tabular}

From Table 12, the employees referring people to join the retail industry is significantly depending on the educational qualifications, total years of work experience in the retail industry and the years of working experience in the present designation of the employees.

\subsection{Testing of Reliability of the Data}

Table 13: Reliability Statistics

\begin{tabular}{|l|l|}
\hline Cronbach's Alpha & N of Items \\
\hline 0.743 & 5 \\
\hline
\end{tabular}

According to the Reliability Statistics in Table 13, the value of Cronbach's Alpha is equal to 0.743, which means that the data is approximately $74 \% \%$ reliable. The general thumb rule is that, for primary data with reliability statistics of $60 \%$ is accepted. Therefore, the survey data can be accepted. 


\subsection{Results of Factor Analysis}

Factor Analysis has been carried out for reduction of variables, influencing the staff motivation in the retail industry.

Table 14: Rotated Component Matrix

\begin{tabular}{|l|l|l|}
\hline \multicolumn{2}{|l|}{} & Component \\
\cline { 2 - 3 } & 1 & 2 \\
\hline How satisfied are you about the career growth opportunities in & 0.822 & -0.278 \\
retail industry & & \\
\hline How satisfied are you with the incentive structure & -0.050 & 0.959 \\
\hline How satisfied are you with the leave structure & 0.730 & 0.491 \\
\hline $\begin{array}{l}\text { How satisfied are you about the reward and recognition structure in } \\
\text { retail industry }\end{array}$ & 0.839 & 0.197 \\
\hline How satisfied are you with the cash benefit structure & 0.851 & -0.072 \\
\hline
\end{tabular}

The statements are grouped in the following factors: -

Factor 1: 1, 3, 4, 5 - Overall Benefits in Retail

Factor 2: 2 - Benefits on Performance in Sales

The outcome of Factor Analysis revealed two factors, which mostly influence the staff motivation in organised retail industry. The first factor, consisting of four statements $(1,3,4,5)$ has been named as Overall Benefits in Retail. The second factor, comprising of one statement (2) has been named as Benefits on Performance in Sales. Career growth opportunities, leave structure, reward and recognition structure and cash benefit structure are the overall benefits provided in the retail industry to keep up the motivation of their staffs. Incentive structure is the benefit provided to the staffs depending on the performance in sales which motivate them to perform better.

\section{Discussion \& Conclusion}

The results of the Chi-Square Test indicate that, there exists significant relationship between the availability of career growth opportunities with the educational qualifications and the present designations of the employees. Moreover, the satisfaction level of the staffs on the career growth opportunities is more significantly related to the present designation, initial designation, and total years of work in the retail industry of the employees. The appropriate availability of the opportunities gives the staffs the hope of making them better off while still working which motivates them to work in the retail industry. The most significant variable in relation with the satisfaction level of the employees on the leave structure is the total working years in the retail industry of the employees. The benefits of proper leave structure help the staffs to relax rest and reflect on their work, which in turn motivates the staffs to perform better with more motivation to work better. The educational qualifications, total working years in the retail industry and years of working experience in the present designation of the employees have the most significance on the satisfaction level of the employees on the reward and recognition structure. The reward and recognition structure makes the staffs feel good about hard work they put in; the appreciative gestures make them feel good about the work they do which motivates them to work better the next time. The satisfaction level of the employees of the employees on cash benefit structure depends most significantly depends on the educational qualification and the years of work experience in the present designation of the employees. The cash benefit structures motivate the staffs to work for their company as they get congratulated and appreciated for having a special event in their personal life like, cash benefits/ gift vouchers provided after getting married, or for having a baby, etc. The satisfaction level of the employees on the incentive structure is most significantly related with present designation and the total years of working in the retail industry of the employees. This sets a target in the minds of the staffs so that they can earn more than usual which encourages them to work better and as they get appreciated with incentives; it also motivates them to work better in future too.

The staffs feel the need to have changes in the incentive structure depending strongly on the significant variables like present designation, total years of working in the retail industry of the employees. The most significant relationship of the perception of the employees for the requirement of trainings is with educational qualifications, total years of working in the retail industry and also years of 
work in the present designation of the employees. The educational qualification, total work experience in retail industry and also work experience in the present designation significantly influences the motivation level of the employees. The achievement of rewards is most significantly influenced by years working in the present designation of the employees. The perception of the staffs about the best factor of working in retail is significantly related to the age, marital status, present designation, initial designation, work experiences in the retail industry of the employees. The educational qualifications and the work experiences in years significantly influence the decision of the staffs about referring people to work in retail industry.

The result of Factor Analysis uncovered two factors, which for the most part impact the attire buys from sorted out retail outlets. The first, comprising of four articulations $(1,3,4,5)$ has been named as Overall Benefits in Retail. The second factor, involving one explanation (2) has been named as Benefits on Performance in Sales. Career growth opportunities, leave structure, reward and recognition structure and cash benefit structure have a great impact on staff motivation in the retail industry. Among these, the career growth opportunities, the reward and recognition structure and the cash benefit structure have a neck-to-neck impact on the employees in motivating them to work better. Incentive structure of the second component named Benefits on Performance in Sales, helps in encouraging the staffs to work better in quality as well as in quantity so that they can hit above the minimum assigned targets which will lead them to earn more than usual. This is highly motivating for the staffs to work better in the retail industry.

The components give an unadulterated and fulfilling experience to the staffs which makes them feel good about their work and also make them feel hopeful in order to make betterment in their career. These leads to positively influencing the motivation level of the staffs in the retail industry. This leads to better performance from the staffs in both quality and quantity. This also reduces employee turnover. This helps in maintaining a healthy environment work balance with a healthy relationship between the staffs and the management, in the retail sector. This in turn helps the retail sector to grow and prosper.

\section{Limitations \& Future Scope}

The present study has been conducted in the city of Kolkata, India. However, future studies may be extended to other parts of the country. Furthermore, the present study involved a sample size of 70. The sample size is small. Future studies can be conducted by using more sample size, to identify any variation in results. Time constraint has been another drawback of the study, and future research can be done in a larger time frame. Moreover, the pandemic of Covid-19 has made psychological changes in the minds of the staffs about the hygiene factors because they come in direct contact with several customers. So, future study can be extended with focus on the post-pandemic era.

\section{Appendix}

Gender: i) Male ii) Female

Age: i) 18- 23 years ii) 23- 28 years iii) 28- 35 years iv) Above 35 years

Marital Status: i) Single ii) Married

Educational Qualification: i) Secondary ii) Higher Secondary iii) Graduate iv) Postgraduate \& above

Your present designation: i) CCA ii) Fashion Consultant iii) Personal Shopper iv) Department Manager

Your next target designation: i) Fashion Consultant ii) Personal Shopper iii) Department Manager iv) Retail Operations Manager

Your initial designation: i) CCA ii) Fashion Consultant iii) Personal Shopper iv) Department Manager

Total years working in retail industry: i) $0-2$ year ii) 2-5 years iii) 5-8 years iv) 8-10 years v) Above 10 years

No. of years working in the present designation: i) 0-1 year ii) 1-2 years iii) 2-3 years iv) 3-5 years v) Above 5 years

Retail industry provided enough opportunities to grow in career: i) Yes ii) No

How satisfied are you about the career growth opportunities in retail industry?

i) Extremely Satisfied ii) Satisfied iii) Neither Satisfied nor Dissatisfied iv) Dissatisfied v) Extremely Dissatisfied

Achieved rewards: i) 0 ii) 1 iii) 2 iv) 3 v) 4 vi) More than 4 times

Best Groomed Employee: i) Never ii) 1-2 times iii) 3-4 times iv) 5 times v) More than 5 times

Best Customer Care Associate: i) Never ii) Once iii) Twice iv) Thrice v) More than Thrice

Best Department Manager: i) Never ii) Once iii) Twice iv) Thrice v) More than Thrice

How satisfied are you with the incentive structure: i) Extremely Satisfied ii) Satisfied iii) Neither Satisfied nor Dissatisfied iv) Dissatisfied v) Extremely Dissatisfied? 
How satisfied are you with the leave structure: i) Extremely Satisfied ii) Satisfied iii) Neither Satisfied nor Dissatisfied iv) Dissatisfied v) Extremely Dissatisfied?

How satisfied are you about the reward and recognition structure in retail industry?

i) Extremely Satisfied ii) Satisfied iii) Neither Satisfied nor Dissatisfied iv) Dissatisfied v) Extremely Dissatisfied

No. of trainings offered to you:

Any training that you require but have not received: i) Yes ii) No

Areas you need to improve yourself.

Your plan on how you want to improve yourself:

How satisfied are you with the cash benefit structure: i) Extremely Satisfied?

ii) Satisfied iii) Neither Satisfied nor Dissatisfied iv) Dissatisfied v) Extremely Dissatisfied

Do you feel any changes are required in the incentive structure: i) Yes ii) No?

Do you feel motivated to work in retail industry? i) Yes ii) No

What is the best factor about working in retail industry? i) Timely salary ii) Good growth opportunity iii) Work culture iv) Supportiveness of the management

Do you refer people to join the retail industry? i) Yes ii) No

Reasons for referring people in retail industry

Where do you see yourself in next 2-3 years?

Your place of interest to work other than operation department.

Your experience of working in retail industry (in your own words):

\section{References}

Dwivedula, Ravikiran and Muller, R., 2011. Work Motivation as a Determinant of Organizational and Professional Commitment in Case of Temporary Organizations: Theoretical Perspectives. International Research Network for Organizing by Projects, 10, pp.1-27.

Gagne, M. and Deci, L., 2005. Self-determination Theory and Work Motivation. Journal of Organizational Behaviour, 26, pp.331-362.

George, L. and Sabapathy, T., 2011. Work Motivation of Teachers: Relationship with Organizational Commitment. Canadian Social Science, 7(1), pp.90-99.

Ghauri, P. and Gronhaug, K., 2002. Business Research Methods in Business Studies: A Practical Guide. 2nd ed. Sydney: Sydney Prentice Hall.

Mohsan, F., Nawaz, M., Khan, M., Shaukat, Z. and Aslam, N., 2004. Are Employees Motivation, Commitment and Job Involvement Inter-related: Evidence from Banking Sector of Pakistan. International Journal of Business and Social Science, 2(17), pp.226-233.

Ramlall, S., 2004. A review of employee motivation theories and their implications for employee retention within organizations. Journal of American Academy of Business, 7, pp.52-63.

Robbins, P. and Judge, T., 2008. Organizational Behavior. 13th ed.

Simon, T. and Enz, C., 1995. Motivating Hotel Employees. Cornell Hotel and Restaurant Administration Quarterly, 36(1), pp.20-27.

Tella, A., Ayeni, O. and Popoola, O., 2007. Work Motivation, Job Satisfaction, and Organisational Commitment of Library Personnel in Academic and Researchn Libraries in Oyo State, Nigeria. Library Philosophy and Practice, 9(2).

Thomas, B. and Velthouse, A., 1990. Cognition Elements of Empowerment: An "Interpretive" Model of Intrinsic Task Motivation. Academy of Management Review, 15, pp.666-681. 